\title{
WOMEN'S ENTRANCE TO THE UNIVERSITY: AMBITIONS, DIFFICULTIES AND THE DESIRE TO PROCEED
}

\author{
O INGRESSO FEMININO NA UNIVERSIDADE: AMBIÇÕES, DIFICULDADES E O DESEJO DE \\ PROSSEGUIR
}

\section{ENTRADA DE LAS MUJERES A LA UNIVERSIDAD: AMBICIONES, DIFICULTADES Y EL DESEO DE PROCEDER}

\author{
Sônia Maria Alves de Oliveira Reis ${ }^{1}$ \\ Samara Gomes Aguiar ${ }^{2}$ \\ Valquiria Normanha Paes ${ }^{3}$
}

\begin{abstract}
This study aimed to analyze, based on the specificities of the female condition, how the permanence and participation of women happens to be: "mothers, wives, housewives or workers" in the Department of Education, Campus XII of the State University of Bahia. It is a research based on the assumptions of the qualitative approach, and considering that it is a field research, it used questionnaires and semi-structured interviews to collect the data, later analyzed with the aid of content analysis. The results show that women have experienced a multiplicity of tasks that have overloaded them, this often forces them to choose between performing duties imposed on them, or studying. It is concluded that the profile of women has changed, and as a result of this the academy can no longer make this public invisible, because in the face of a numerical predominance and substantial majority, they now act as protagonists of their own lives.
\end{abstract}

Keywords: Women. University. Entrance.

Resumo: Este trabalho objetivou analisar, a partir das especificidades da condição feminina, como acontece a permanência e a participação de mulheres que são: "mães, esposas, donas de casa ou trabalhadoras" no Departamento de Educação, Campus XII da Universidade do Estado da Bahia. Tratase de uma pesquisa de campo, fundamentada nos pressupostos da abordagem qualitativa. Valeu-se de questionários e entrevistas semiestruturadas para coletar os dados, posteriormente analisados com o auxílio da análise de conteúdo. Os resultados apontam que as mulheres têm experienciado uma multiplicidade de tarefas que as tem sobrecarregado, isso muitas vezes as obriga a escolher entre desempenhar funções que lhe são impostas, ou estudar. Conclui-se que o perfil das mulheres mudou,

\footnotetext{
${ }^{1}$ State University of Bahia. Guanambi, Bahia, Brazil.

${ }^{2}$ State University of Southwest Bahia. Vitória da Conquista, Bahia, Brazil.

${ }^{3}$ State University of Bahia. Guanambi, Bahia, Brazil.
} 
e em virtude disso a academia não pode mais invisibilizar esse público, pois diante de um predomínio numérico e maioria substancial, atuam agora como protagonistas de suas próprias vidas.

Palavras-chave: Mulheres. Universidade. Ingresso.

Resumen: Este estudio tuvo como objetivo analizar, con base en las especificidades de la condición femenina, cómo la permanencia y la participación de las mujeres son: "madres, esposas, amas de casa o trabajadoras" en el Departamento de Educación, Campus XII de la Universidad Estatal de Bahía. Es una investigación basada en los supuestos del enfoque cualitativo, y considerando que es una investigación de campo, utilizó cuestionarios y entrevistas semiestructuradas para recopilar los datos, que luego se analizaron con la ayuda del análisis de contenido. Los resultados muestran que las mujeres han experimentado una multitud de tareas que las han sobrecargado, lo que a menudo las obliga a elegir entre realizar tareas que se les imponen o estudiar. Se concluye que el perfil de las mujeres ha cambiado, y como resultado de esto, la academia ya no puede hacer que este público sea invisible, porque ante un predominio numérico y una mayoría sustancial, ahora actúan como protagonistas de sus propias vidas.

Palabras clave: Mujer. Universidad. Entrada.

\section{CURRENT FEMALE CONDITION AT THE UNIVERSITY}

Analyzing the history of humanity, it can be seen that every society, regardless of the time in which it finds itself, is the result of a previous construction that is never finished, on the contrary, it is continuous and gradual. The Brazilian social organization has been consolidated in the same way, facing a succession of facts and factors that transformed it into what it is today. There were several pillars that sustained it during its structuring, so it is fitting to say that we are the result of a past built on innumerable concepts and certainties that shaped the current reality.

One of these conceptions, which is not exclusive to the Brazilian reality, refers to patriarchy. This ideal of male sovereignty that is embedded in the genesis of our society, and so many others, has generated countless consequences for women, in different aspects of their lives, as they are a collective that for a long time, found themselves on the subjugated side of the context. It is only in the last years of the 20th century, thanks to a long path of struggles, that the female public began to experience the changes planted in a past of resistance and clashes against all forms of domination to which they had been subjected.

Even in the midst of a changing scenario, the consequences created by gender inequality cannot be ignored. There are many implications of this in our daily lives, in the way we think and act, in the way we organize ourselves socially and politically, thus exercising a 
direct influence on various aspects such as laws and rights, or their denial. In view of this, it is possible to perceive about the relevance of the topic academic women who are: "mothers, wives, housewives or workers", since university is a space that defends the need for inclusion and also acts as an environment for as such, it thus becomes a propitious place for the claim of the rights of groups that aspire to change.

In view of the concerns raised above, this text intends to present, based on the specificities of the female condition, how the permanence and participation of women in Higher Education happens. In addition, it aims to discuss the multiple perceptions, the main motivations and the condition of the woman: "mother, wife, housewife or worker" in the university context.

The choice for this theme was first awakened in the context of our classroom, as we noticed the limitations that some colleagues who fit into one or all of the conditions of: "mothers, wives, housewives or workers" had at the time to dedicate themselves to academic activities, since their other "obligations", outside the university scenario, were also seen as a

priority, and this "failure" in the attempt to reconcile frustrated the students in such a way that the constant speeches about dissatisfaction ended up disturbing us. Their biggest complaints were related to the impasses they narrated when facing the harmonization of these various tasks, which were often imposed on them, albeit in a symbolic way.

The reflections we present now signal the need for university women to recognize the value of their own struggles, so that, thus, they take their place in the search for their rights and realize that they are not alone in the journey that is the academic life of women. They also point out how important it is to denaturalize the situation of student mothers who need to take their children with them to the classroom, because the naturalization of the facts prevents solutions from being pointed out, since everything that is considered normal is not questioned, and in this way it is perpetuated without prospects for change.

\section{METHODOLOGICAL PATHS}

For this study to be prepared to analyze, based on the specificities of the female condition, how the permanence and participation of women happens in the Department of Education, Campus XII of the State University of Bahia, we decided to conduct a field research, with a qualitative approach, result of a Scientific Initiation $(\mathrm{Cl})$ research and conclusion work of an undergraduate course in Pedagogy. 
In order to realize the idealization of research that had been done in the $\mathrm{Cl}$, some strategies were designed to arrive at the results of this investigation. At first, it was defined that a field research would be carried out, as it allows a closer contact between the researcher and the subjects and the place of analysis, since it requires going to the environment and this makes it possible to create a greater bond with the universe to be observed. The merit of the field investigation occurs at the point where this type of analysis provides subsidies for the researcher to understand in depth the subjects and the context in which they are inserted, facilitating the analysis and understanding the researched environment and the phenomena that happen there.

The use of qualitative research procedures helped to understand the problem context in a wide way, allowing us to know the singularities and regularities of women who experience one or all of the conditions established by the study. Because it is an inductive resource that seeks to understand why the individual acts the way he or she acts, thinks the way he thinks or feels the way he feels, he best met the needs of this investigation, since the answers in depth are generated mainly through the qualitative approach, since it "answers very specific questions [...], works with the universe of meanings, motives, aspirations, beliefs, values and attitudes" (MINAYO, 2002, p. 21).

To define the type of research we consider that for an investigation to be considered exploratory in nature, the researcher must seek to ascertain his research problem in order to provide more concise information about the study, seeking not only to describe the facts that involve concern, but also to understand the motivations that led the situation to what it has become, aiming to offer possible solutions to the issue (MARCONI; LAKATOS, 2003). In this perspective, the research was also carried out in an explanatory manner, since it sought to explain, from the exploration of the collected data, what are the conditions of presence and performance of women who are included in one or all of the conditions of: "mothers, wives, housewives or workers" in Higher Education.

The educational institution chosen as the locus of the research was the Department of Education, Campus XII, of the State University of Bahia, located in the city of Guanambi / BA. This choice was due to the fact that it was the place where we studied in 2018 and also because we observed in this space the limitations that women, under the conditions established here, faced when they needed to dedicate themselves to academic activities. 
The research collaborators were female students, aged between 17 and 54 years old, who fit all or some of the defined conditions.

For the collection of data with the students, 135 questionnaires were given to them, and of these, 116 were returned. Of this number of students, 15 were taking Administration, 14 Nursing, 17 Physical Education, 69 Pedagogy and only 1 of them did not specify the course. Among these, 95 are mothers and 21 at the time of the research they were not, that is, the research was carried out mainly with women mothers, and who, in addition to this condition, still add the functions of housewives, wives and in some cases still have a job paid outside the home. It is worth noting that the 21 who were not mothers were selected because they met at least one of the research criteria, that is, even if they did not have children / the collaborators or were housewives ${ }^{4}$, or wives or had a paid job.

To meet the need to collect more personal information in relation to the undergraduate students' view of the way their academic trajectory was happening, a semistructured questionnaire was used in the study. It is defined as the fastest way to obtain information, being very effective because it does not require training of personnel and, still, more securely guarantee the anonymity of those involved (GIL, 2010).

After returning the questionnaires, data were tabulated. At first, all the information related to the participants' profiles was organized and recorded in an Excel spreadsheet, then all the answers were listed for each question and, after that, the data were separated by categories (age profile, cities of origin, housing situation and others).

Only then was it possible to identify which students made themselves available to participate in the next phase of the investigation, which would be the interviews. All those who answered the questionnaires were invited, but many of them did not wish to collaborate in the second stage of the process. For those who wanted, the criterion of choice was given to mix the number of students per course, to better understand the different contexts of the 4 courses $^{5}$ offered by Campus XII - UNEB.

In addition to the intention of listening to students from all educational segments, their selection took place based on other motivations. The conditions of each of the women were considered, since it was not intended to interview only those with similar profiles, such as only

\footnotetext{
${ }^{4}$ In this research, women are assumed to be housewives who (married or not, mothers or not, workers or not) perform alone, or most domestic activities, such as cleaning the house, washing clothes, among others.

${ }^{5}$ DEDC XII - UNEB offers courses in Nursing, Pedagogy, Physical Education and Administration.
} 
mothers or only wives. Still the socioeconomic profile, since considering the barrier of the financial condition as a variant that makes the academic trajectory of these women even more difficult, preference was given to those who defined themselves as low income.

With these questions delimited, we then elaborated some questions composed in the corpus of the interview, which was later carried out with the participants, intending to understand how they perceived their presence and participation in Higher Education. The interview was previously scheduled with the students and, pondering about the many jobs they perform beyond university life, the conversations were held at DEDC XII itself, at times that were more comfortable for the participants.

The choice to use the interview was due to the fact that this technique allows the interviewee to have the freedom to express himself in a more spontaneous way, debating and exposing his opinion on a certain topic. It can be conceptualized as the procedure by which the investigated person presents himself / herself as a human source of information for the researcher and he / she asks him / her questions, aiming to collect data that foment the research progress and objectives (GIL, 2010).

This study sought to assimilate theoretical concepts to a set of instruments that would make it possible to know the particular interpretations of the experiences of women in the conditions of: "mothers, wives, housewives or workers", who deal with the difficulties to remain in the public university, given the everyday circumstances in which they are often forcibly inserted.

The analysis of the qualitative data produced during the investigation was directed based on the content analysis, as it is the process by which order, structure and meaning are given to the information that is reached during the research. It also consists of transforming this information into conclusions and useful information for the study, since it is "an empirical method, a set of instruments in constant refinement, which applies to diversified speeches and which mainly refers to the description objective, systematic and quantitative content, without, therefore, ceasing to be an analysis of meanings" (BARDIN, 2011, p. 15). Based on this statement, the different phases of content analysis were organized around three chronological poles: pre-analysis, material exploration and, finally, the treatment of results, which were subdivided into inference and interpretation. 


\section{MULTIPLE PERCEPTIONS ABOUT WOMEN'S ENTRANCE TO THE UNIVERSITY}

There are some questions related to the entry of women in certain conditions at the university that disturbed us a lot during the construction of this investigation, the main ones being: is the academic space really belonging to them? Is he prepared to receive them? Are you willing to change to accommodate them? What specific actions should be thought of in order to help in the academic life of these current women, since they have fit into certain situations that differentiate them from other students? When these questions are considered in depth, it is possible to identify numerous other issues that are also interwoven with the student trajectory of women in Higher Education.

In view of their numerical predominance and even their stay in specific conditions, there is no question why this space is still so resistant to changes that help and facilitate the permanence of this public in their environment, since the difficulty in reconciling the multiple roles and tasks they have is a determining factor for the abandonment of a large part of this group.

The social transformation, as well as the change in the family structure, can elucidate the attribution of so many functions to women, "this fact brought changes not only to the routine of contemporary women, but also to their life projects and their consequent choices" (LOPES; ZANON; BOECKEL, 2014, p. 918).

When asked about their biggest concerns at the moment they found out that they had passed the entrance exam, all of them who were mothers, and most of whom were married, at first were concerned with the removal and care of their children, since the dealing with children to be considered an exclusively feminine work is something historically constructed and that continues today, bringing many consequences for the present of this public.

In short, the students affirm that the biggest concern was the difficulty of having a small daughter and not being able to reconcile to keep me until the end of the course (ÁRTEMIS6, 20/04/2018). Another student agrees saying that she feared for not being able to

\footnotetext{
${ }^{6}$ In order to preserve the identity of the research collaborators, we chose to identify them with the names of characters from Greek mythology, since we note that the academic path of each one of them was and has been marked by countless challenges, resistance and overcoming, as well as that of the referenced mythological women.
} 
reconcile a double life, mainly with the monitoring and development of my daughter, since I stay out all day and study at night (ATENA, 12/05/2018).

Nodding, some more students mention that the biggest fears were to give up some moments of being close to my daughter (DEMÉTER, 06/22/2018), or who would take care of my daughter while I was in college (HERA, 17 / 04/2018), or even what to do with my son who was only two years old (HEMERA, 05/02/2018).

The removal of their children was a dilemma frequently mentioned by the students, having as aggravating the fact that those who were unable to even take the children with them to the classroom were forced to leave them under the care of other people, usually family members, mostly grandmothers:

The biggest challenge I face I think is to overcome the distance, because I have to stay away from my daughter, as I practically spend all day in college, so my biggest challenge to continue studying is to overcome this distance from my daughter [. ..] what hurts me most is the fact of being away from her. (TALASSA, 10/26/2018).

A constancy was noted in this aspect, since for most of the students one of the greatest fears was that they would no longer be able to count on the help of their mother or mother-in-law to take care of their children, as they were unable to pay someone to do it, and so the only alternative would be to abandon the course. The outstanding issue here refers to the obligations of motherhood overlapping the desire to study for these women, a situation that causes delays in educational entrance, dropping out of further studies and discontinuity in the work plan. All of this arises as a result of the suspension of the educational and professional career for the care of small children, as it means a deceleration of activities and the return, when it occurs, comes loaded with numerous difficulties, whether when the woman becomes is in the condition of professional or student, thus impairing their educational or professional pursuit.

Another recurring concern was how they would harmonize the various tasks they already had with the new experiences that the academy would bring. They report that they were afraid of not being able to reconcile domestic work with academic activities [...] a mixture of concern, happiness and fear, as they were already aware that things at UNEB were not easy (MEDUSA, 04/2018), or reconcile work with studies, find time to study and take care of the home and husband (GAIA, 04/2018), even if I would be able to reconcile study and work (NIX, 
05/2018) and still reconcile the whole life that I had before, with college and leaving my daughter (IRIS, 04/17/2018).

Even though it is in a historical period that allows the questioning about certain imposed obligations, it is noted that the path to the changes that such questions offer still advances at a slow pace, because in the face of statements such as the concern was with whom I could leave my son to come to the university, pay for transportation, as would stay (FEBE, 04/16/2018), or if I was going to take care of a small son, home and college activities (TÉlA, 04/16/2018), it's easy realize how the question of women being forced to choose between studies, motherhood or marriage and their obligations, is still rooted in our society. Although in a veiled way, what we can see is that there is a kind of culture of social punishment because they are no longer exclusively available to the home.

Another point worth mentioning is related to transportation, the third most periodic concern of students, especially for those who live outside the city where Campus XII is located, since the biggest fear was related to the issue of transportation, since I live in another city (TÉTIS, 05/2018), that is, the displacement from Riacho de Santana to Guanambi (FREYA, 04/20/2018).

University transport is not guaranteed in all municipalities. Whether or not the guarantee depends on the city or district in question. In general, the Law that is responsible for driving students is No. 9,394 / 96, which acts in addition to Law No. 10,709 / 2003, which provides for the right of the student to use school transport.

Paragraph VII of Art. 208 of the 1988 Federal Constitution delimits that it is the duty of the State with education to "guarantee the service to the student, in all stages of basic education, through supplementary programs of didactic-school material, transportation, food and health care "(BRASIL, 1988). Art. 10, on the other hand, defines that the States should be in charge of the school transport of the students of the state network and Art. 11 guarantees that the municipalities will assume the school transport of the students of the municipal network.

Faced with statements, as being from another city other than the university, my biggest concern was the transportation that the city does not provide (PERSÉFONE, 06/2018) and the lack of public transportation compatible with the full course schedule and the financial need to be paying for another transport (DORIS, 04/26/2018) it can be concluded that there are no security guards to support university students regarding their transport, since the States and 
Municipalities are defined that they must provide driving to the students / those of the state and municipal networks, however, to university students this guarantee is not extended.

Precisely due to the statements mentioned above, the issue of transportation appears as an impediment in what refers to the studies of the researched academics, since most of them reported about the difficulty they have in financing a private vehicle and the municipalities of their municipalities do not provide free buses. Therefore, the financial issue also stands out as an obstacle to the students' permanence in the university.

In short, they comment that they encounter obstacles with the lack of transportation, having to hitchhike (HÉSTIA, 10/26/2018), the financial issue, as they have a lot of expenses (QUELONE, 10/26/2018), or mainly the expense which is very high, so work to keep college, keep the house and take care of the baby (MAIA, 10/26/2018). Corroborating with the students mentioned above, another student also states that:

What matters most is the financial, because then you don't have time to work anymore, because you get there at 1:30 pm, then you can't work in the afternoon anymore, and the children can't work at night [...] also the lack of scholarships, right, because there are few so not everyone receives it, this makes it a bit difficult. (HÉSTIA, 10/26/2018).

They also narrated that they go through such situations of financial instability because, failing to reconcile the many tasks, they had to choose between studying or working, and in this case, they prioritized the study over a job, and in view of that, considering that neither all women manage to reconcile academic life with the other functions they perform, it is essential to think about female evasion from higher education.

When analyzed, the responses of the students revealed that at some point they thought of giving up their studies due to the many difficulties they face daily, not seeing the possibility of improvement in the face of these impasses. The majority mentions that even if they continued in the course at some point, they considered abandoning it, since greater reasons were at work. There are many justifications, mention that they live in cities very far from the Campus, they are unable to cope with academic, domestic and maternal activities, or studies and work.

Some of the participants said that what inhibited them from leaving Higher Education was the acquisition of some scholarship, whether it was for student aid or not, since programs such as Scientific Initiation (CI) and the Teaching Initiation Program (PIBID), even not being 
configured as an assistance policy, they also help these students to stay at the university, since "student assistance, as a social law mechanism, aims to provide the necessary resources to overcome obstacles and overcome impediments to good academic performance" (VASCONCELOS, 2010, p. 609).

Agreeing, one student says that what prevented me was the granting of aid that helped me to continue as the PIBID and Mais Futuro scholarship (METIS, 03/05/2018).

What is evident is that with the expansion of Higher Education, insertion has become more accessible, but permanence has not, since several determining factors act on these women, taking them along paths that sometimes leave no choice but to abandon them. , withdrawal or postponement of studies.

When it comes to aid, it is important to remember that they intend not to privilege some / but few, but the search for bridging the gap between those who need help or not. What is sought is the viability of conditions. Without help, it is equivalent to saying that all individuals, without exception, have the right to climb Mount Eiger or Mount Everest, provided, of course, they are excellent climbers and have the institutional and financial resources to do so (MOREIRA; SILVA, 2000).

It is necessary to think of the less favored groups in order to consider their subjectivities, intending to help them in the continuity of their studies, because the difficult is not to enter, the difficult is to remain (HEBE, 16/04/2018). Therefore, it is necessary to mobilize the less privileged who intend to enforce their rights, which can be done through pressure against the public power, until it offers decent study conditions for all that want.

\section{AMBITIONS AND PERSPECTIVES: REASONS THAT LEAD TO ACTION}

Higher education has been constituted throughout the history of Brazilian education, as an educational level of greater complexity due to the various confrontations it makes about the existing social challenges. Starting from the assumption that society sees Higher Education as an alternative of professionalization with a higher social status (SPARTA; GOMES, 2005), before seeking to enter this educational modality, many people are encouraged by someone who has already passed through this space or even for those who never had the opportunity, but who see importance and value in it. In view of this, it is argued that the incentive can be decisive for success in what it aims to achieve within this scenario. 
In this perspective, a student says that her greatest motivations for the study are professional and personal fulfillment as well, as I am the first of the family of 11 brothers to be at the public university, in addition to [...] the professional motivation to give a better condition in the future of life for my daughter (TÁLASSA, 10/26/2018).

Considering this speech and in view of the analysis of the collected data, it was observed that practically all the participants, even having their own aspirations in relation to Higher Education, have motivations that go far beyond that.

Most cite that they got encouragement mainly from mothers, family, children, friends, siblings, spouses and even high school teachers. Those who say that they received encouragement from their family make it clear that this support is laden with desires and dreams that these people were unable to fulfill, but still wish to see realized through their daughters.

They say that the assistance offered by the mothers was the most significant, since their participation in the lives of these students is essential for their permanence in the academy. This discussion is contemplated in the speech of two students, the first reports that [...] I cannot even imagine what I would do if I did not have the help and support of my mother, and, second, my husband, who encourages me, helping always and in everything he can (AFRODITE, 04/18/2018). In agreement with this statement, another student says that she gets stronger in her [...] son and my mother, because [...] because I am from the country and have a very precarious condition, I always dreamed of taking a course higher education to give a better condition for my mother and now for my son (MAIA, 10/26/2018).

Nodding, other students narrate that they also have the greatest incentives for their children. They say that whenever the thought of abandonment arose, they tried to remember that they were not in that space just for them, that it was a time of formation so that later on they could offer people who love a better future, with more opportunities. The statements of two students complement each other when they say that:

[...] I don't think so much about me, but it's because of my children, because for me this is just a baggage for me to work, it's just for me to specialize, right, so I can have a profession and be able to work and give my children something better. (HÉSTIA, 10/26/2018).

[...] I know I have my need, but when I think about my children, I think I can be a better mother, especially in the Pedagogy course, so that makes me not lose sight of the intention of being graduating even for their sake, to be 
instructed so that they have me, in a way, as an example, because a mother who studies is inspiration. The child who sees his parents doing some activity on a daily basis, they will already be used to seeing this activity, so what I do is for me and for them, and it is beneficial for the whole family. (MINERVA, 10/25/2018).

Thus, it is possible to see that their incentives are quite diverse, ranging from the desire for knowledge to the desire to be inspiration for their children and offer a more comfortable life for those who love or depend on them.

There were also those who received support from the sisters who are already graduates and recognize the quality of education offered by Campus XII, highlighting the importance of human and professional training that UNEB enables. Those who reported receiving support from Basic Education teachers signal the influence that entry into Higher Education has during High School, since teachers strive to offer favorable conditions for their students / manage to enter undergraduate courses and become more capable and successful professionals.

Of the public surveyed, only 4 women reported that they did not have nor have support from family members to continue studying, however, they say that they are motivated all the time by colleagues who are inspired by the struggle of other women who helped in the achievement of female emancipation, that and your own ambitions to not give up.

\section{THE CONDITION OF THE WOMAN, MOTHER, HOUSEHOLD, WIFE AND WORKER AT THE UNIVERSITY: I HAVE TO CHOOSE BETWEEN READING AN APOSTILE AND WASHING CLOTHES?}

Since education has consolidated itself as a field that made it possible to improve living conditions, education has been conducted in order to enable men to get good jobs and positions, whereas that of girls has always been marked by restrictions, even non-existence in some periods. This happened because the vision of an adequate woman was, still is, that who stayed at home, taking care of children and domestic duties, "in the case of Brazil, by tradition and custom, women were responsible for domestic duties and also for the moral support to the family. Thus, female education focused on preparing their destiny as wives and mothers" (SAMARA, 2006, p. 86). There was, therefore, no need to offer studies other than those

\footnotetext{
${ }^{7}$ Zemina (17/04/2018).
} 
considered suitable for female nature. The highest position they were supposed to reach was that of home secretaries, and that was enough for them.

Starting from this statement, a student says that, as a woman, her greatest anguish is related to the feeling of overload that she has in front of the many obligations that are meant for her:

There are many household chores. It's terrible. Because being a woman, historically, socially and culturally, these tasks were imposed on us and unfortunately it is still today. Sometimes I have to choose between reading a handout and washing clothes. And housework is endless. Every day and all the time you have things to do. And when you are a married woman, the charge increases, not only on the part of the husband, but by the women of the family, such as: mother, sisters, and aunts. So domestic activities are a great difficulty because the time that I could be devoting to studies I am taking care of the chores of the home. (ZEMINA, 04/17/2018).

This student explains well the frustration of many university women when they are forced to choose between doing homework or university duties. Sometimes I have to choose between reading a book and washing clothes, this statement signals two very important things. The first is that the sharing of domestic work still takes place based on gender, with women being the noun most affected by this unequal and unfair split, since it is on her that the greatest responsibilities have been placed.

The second point refers to the dissatisfaction that this situation causes in women, since she also says that domestic service is endless, so it is never ending to choose it only once, resignations are made daily, and thus end up prioritizing domestic services to the detriment of studies. Women are limited to the domestic scenario, which contributes little to the achievement of their professional autonomy.

She also highlights the process of building this thought, when she mentions that because she is a woman, historically, socially and culturally, these tasks were imposed on us and unfortunately it is still today. This student shares the same view of some authors who assure that women feel the need to reduce the workload or study hours, as the partner is not available to share care with them. Children and domestic chores, most of the time, and this situation in which she is placed directly influences countless aspects of her life, ranging from her health to her professionalization, or lack of it (FIORIN; OLIVEIRA; DIAS, 2014). 
Thus, they do not perform a job that they consider satisfactory in any context, it is as if they are constantly divided and hoping to leave one task to accomplish the next, in an infinite cycle of dissatisfaction with themselves, as a student explains when she reports that:

[...] you will look for your way of being reconciling everything, there is a way for everything, at first I had this concern about what it would be like, during pregnancy I was already worried about what I would do with my whole routine of being the mother of the second baby, with the housewife routine, and I still try to work, make an extra income, and as a college student I thought that it wouldn't make any sense, that something would be badly done, but it has to question of the time that is very short, but I try to be managing. What works for me to do today? What activities do I have? I try to reconcile, even if I am not $100 \%$ successful, I do it, trying to manage time [...]. (MINERVA, 10/25/2018).

The transformations that occurred in the social organization, at work and in the family, caused changes in the ways of life, making the need to reconcile work, domestic activities and motherhood become one of the greatest current impasses for women. This modification generated real conflicts that are difficult to be overcome, since, on the one hand, there is a need for female professionalization, since the number of single women who provide home care is increasing, and on the other hand, the dedication to children, because the number of solo mothers is also growing.

Another point highlighted by the students is related to the lack of time for leisure, due to the many activities they have to cope with. Those who are mothers consider leisure the act of being with their children, because, due to the fact that they feel guilty for being distant while studying or working, they convert all their free time into an opportunity to be with the children. In view of this, the issue of leisure for university women cannot be ignored, as it is important to have a balance between work and personal life, seeking to preserve physical and mental health, allowing them to enjoy pleasurable and idle moments, recognizing the health as a fundamental right, including leisure (REUSCH; SCHWINN, 2015).

As long as the conception that it is only won through an intense effort, sacrifice and self-sacrifice still exists, it is extremely necessary to consider leisure as something indispensable to the quality of life of any person, as moments of rest are also essential for the maintenance of the individuals' mental and physical health. 
The others say they miss spending more time with family or friends and some even mention their religious circle, in which they had to decrease their participation to dedicate themselves to studies. One student says she would like to have more time:

[...] to dedicate myself to my family, for moments of leisure, the tiredness of the study day, of being a mother, housewife, wife and feeling that I am not doing well in these situations, the feeling that I am not achieving the success I would like neither at university nor at home. (LINFA, 04/20/2018).

This speech brings us to an aspect also common to female students, and which has already been mentioned in this study, their dissatisfaction with themselves when they are unable to reconcile their various roles. They report that most of the time they feel incapable and guilty. The age profile of the research varies from 17 to 54 years old, the retro young woman mentioned is in the first decades of life and considering the many obligations that she already has to perform, it is understandable why she is so frustrated, as it is noted that she already realizes the difficulty in harmonizing so many charges.

Some consequences, inherited from patriarchy, are easily identified in this feeling of guilt that many women feel when, even though they are thinking about improving family life, they have a double or sometimes triple workday, often having to leave their children / with relatives or acquaintances to be able to cope with the multiple functions they have to perform, "for contemporary women, working and being a successful professional means adding responsibilities, more than this is, often, supporting certain conflict measures and fault" (BORSA; FEIL, 2008, p. 08).

In addition to adding paid work outside the home, the student profession and motherhood, domestic activities are also almost exclusively under the female responsibility, and thus the woman ends up undergoing many sacrifices in order to meet the various expectations that should not fall only about it.

\section{SOME FINAL CONSIDERATIONS OF A DISCUSSION THAT CONTINUES}

The intention of this article was to expose students from DEDC, Campus XII of UNEB who are: "mothers, wives, housewives or workers" perceive their insertion, permanence and performance in the university. 
One of the most evident facts in this study was that even though women are a considerable majority in the academic environment, they still live together, and are affected, with several consequences of a past that limited them in several areas.

The situations in which they are forced to choose between continuing their studies or dedicating themselves to their family and children are not uncommon, a circumstance that signals how the inheritances of an educational exclusion to which they have been subjected are still visible. The creation of the stereotype of "superwoman" also harmed them in several ways, as it normalized the conjuncture of sacrifices and abdications to which they are subjected because they still think that they must reconcile at all costs at all costs, which most of the times are imposed on them.

Given all that was analyzed it was possible to realize that even having achieved many conquests the female public still faces innumerable dilemmas when it comes to studying, not being, however, impasses related only to academic life, are not conventional difficulties that anyone who deciding to go to university would find, they refer to adversities that they face only because they are women and carry with them the weight that this noun implies.

Thus, what was noticeable was that the admission of the participants to the university was cause for great joy, but it was accompanied by several concerns, due to the obligations that these women already had before the approval. The most recurrent fear was related to the issue of caring for children, with whom to leave them while they went to class and they would still be able to harmonize all the chores they already had with the new experiences and demands that the university would bring.

For those who lived far from the university, a major concern was about how they would move to the university campus, since public school transport is not guaranteed for students of Higher Education in all municipalities, and their financial conditions did not allow the cost of a particular drive.

It is thus seen that even with the struggles waged by feminist movements that aimed at the inclusion of women in the affairs of society, unfortunately still in the 21st century, issues such as the unequal division of domestic work and the treatment of children still tend to weighing more on the female shoulders, since they are obligations imposed, historically and socially on women, and only in recent years have they started to be questioned with a view to generating changes. 
What is necessary and urgent is the mobilization of these women, who have unique conditions and are, therefore, an invisible collective in the university environment, so that they pressure public agencies, until they start offering appropriate conditions of studies to these women. They must create conditions that propel them towards the conquest of new spaces and empowerment, both inside and outside the home.

To conclude, albeit temporarily, from all the issues raised here, what we advocate is the improvement of perceptions regarding women. It must be conceived that they are not included in the stereotype of "superwoman" because they want to, but because they are conditioned and often compelled to do so. "Super" they only have the will to win, even in the face of all difficulties, even with their needs invisible.

In the face of everything that has been exposed, for those who seek changes, not only for themselves, but for all those who need, it is impossible to continue to enjoy the university without considering the demands of the collectives that they keep standing, since the spaces only have relevance insofar as they contemplate the people who are in them.

May our daily practice serve, not to maintain the privileges of smaller, but dominant classes, but to offer equity so that everyone, regardless of gender, ethnicity, social class, has the possibility to be where they want and not be prevented the conditions to which they are subject.

\section{Referências}

AMADO, João da Silva. Construir a disciplina para um ensino de qualidade. Revista Práxis Educacional, Vitória da Conquista, v.4, n. 5, jun./dez. 2008. Disponível em:

http://periodicos2.uesb.br/index.php/praxis/article/view/574. Acesso em: 15 nov. 2018.

BARDIN, Laurence. Análise de conteúdo. RETO, Luís Antero; PINHEIRO, Augusto (trads.) Lisboa: Edições 70, 1977.

BORSA, Juliane Callegaro; FEIL, Cristiane Friedrich. O papel da mulher no contexto familiar: uma breve reflexão. O portal dos psicólogos. Porto Alegre/RS, 2008. Disponível em:

http://www.googleacademico.com.br/. Acesso em: 09 nov. 2018.

BRASIL. Constituição (1988). Constituição da República Federativa do Brasil de 1988. Disponível em: http://www.planalto.gov.br/ccivil 03/leis/19394.htm. Acesso em: 09 nov. 2018. 
COSTA, Ana Sheila Fernandes; AKKARI, Abdeljalil; SILVA, Rossana Valéria Souza. Educação básica no Brasil: políticas públicas e qualidade. Revista Práxis Educacional, Vitória da Conquista, v.7, n. 11, jun./dez. 2011. Disponível em:

http://periodicos2.uesb.br/index.php/praxis/article/view/666. Acesso em: 13 nov. 2018.

DUARTE, Alexandre William Barbosa; OLIVEIRA, Dalila Andrade. Valorização profissional docente nos sistemas de ensino de Minas Gerais e Pernambuco. Revista Práxis Educacional, Vitória da Conquista, v.10, n. 17, jun./dez. 2014. Disponível em:

http://periodicos2.uesb.br/index.php/praxis/article/view/780. Acesso em: 14 nov. 2018.

EUGÊNIO, Benedito Gonçalves. O currículo na educação de jovens e adultos: entre o formal e o cotidiano numa escola municipal em belo horizonte. Revista Práxis Educacional, Vitória da Conquista, v. 4, n. 4, jan./jun. 2008. Disponível em:

https://periodicos2.uesb.br/index.php/praxis/article/view/570. Acesso em: 13 nov. 2018.

FREIRA, Maria Auxiliadora S. Práxis pedagógica e professores intelectuais: refletindo as tensões e concepções da formação/prática docente. Revista Práxis Educacional, Vitória da Conquista, v.1, n. 1, jan./dez. 2005. Disponível em:

http://periodicos2.uesb.br/index.php/praxis/article/view/485. Acesso em: 12 nov. 2018.

FIORIN, Pascale Chechi; OLIVEIRA, Clarissa Tochetto de; DIAS, Ana Cristina Garcia.

Percepções de mulheres sobre a relação entre trabalho e maternidade. Revista Brasileira de Orientação Profissional. São Paulo, v. 15. n. 1. p. 25-35. 2014. Disponível em:

http://pepsic.bvsalud.org/pdf/rbop/v15n1/05.pdf. Acesso em: 02 jul. 2018.

GIL, Antônio Carlos. Como elaborar projetos de pesquisa. 5. ed. São Paulo: Atlas, 2010.

ILHA, Franciele Roos da Silva; HYPOLITO, Álvaro Moreira. O trabalho docente no início da carreira e sua contribuição para o desenvolvimento profissional do professor. Revista Práxis Educacional, Vitória da Conquista, v.10, n. 17, jun./dez. 2014. Disponível em:

http://periodicos2.uesb.br/index.php/praxis/article/view/781. Acesso em: 14 nov. 2018.

LOPES, Manuela Nunes; ZANON, Letícia Lovato Dellazzana; BOECKEL, Mariana Gonçalves. A multiplicidade de papéis da mulher contemporânea e a maternidade tardia. Temas em Psicologia. Ribeirão Preto, vol. 22, n. 4. p. 917-928. 2014. Disponível em: http://pepsic.bvsalud.org/pdf/tp/v22n4/v22n04a18.pdf. Acesso em: 12 nov. 2018.

MOREIRA, Antonio Flávio; SILVA, Tomaz Tadeu da (Org.). Currículo, cultura e sociedade. São Paulo: Cortez, 2000.

MOREIRA, Antonio Flavio; JÚNIOR, Paulo Melgaço da Silva. Currículo, Transgressão e Diálogo: quando outras possibilidades se tornam necessárias. Revista Tempos e Espaços em Educação. v. 9, n. 18, p. 45-54, 2016. Disponível em: https://seer.ufs.br/index.php/revtee/article/view/4962/4097. Acesso em: 14 nov. 2018.

MINAYO, Maria Cecília de Souza (Org.). Pesquisa Social: teoria, método e criatividade. 21. ed. Petrópolis: Vozes, 2002. 
NASCIMENTO, L. F.; CAVALCANTE, M. M. D. Abordagem quantitativa na pesquisa em educação: investigações no cotidiano escolar. Revista Tempos e Espaços em Educação, v. 11, n. 25, p. 249-260, 29 mar. 2018. Disponível em: https://seer.ufs.br/index.php/revtee/article/view/7075 Doi: https://doi.org/10.20952/revtee.v11i25.7075

PARASKEVA, J. M. "Brutti, Sporchi \& Cattivi": Towards a Non-Abyssal Curriculum. Revista Tempos e Espaços em Educação, v. 9, n. 18, p. 75-90, 2016. Disponível em: https://seer.ufs.br/index.php/revtee/article/view/4966

Doi: https://doi.org/10.20952/revtee.v9i18.4966

PEREZ, Marcia Cristina Argenti. Infância e escolarização: discutindo a relação família, escola e as especificidades da infância na escola. Revista Práxis Educacional, Vitória da Conquista, v. 8, $\quad$ n. 12 , jan./jun. 2012. Disponível em: http://periodicos2.uesb.br/index.php/praxis/article/view/684. Acesso em: 13 nov. 2018.

REUSCH, Patrícia Thomas; SCHWINN, Simone Andrea. Novas tecnologias e trabalho: 0 trabalho feminino e o direito à desconexão. Revista EDUNISC. Santa Cruz do Sul, 2015. Disponível em: https://online.unisc.br/acadnet/anais/index.php/sidspp/article/view/13172. Acesso em: 11 nov. 2018.

SAMARA, Eni de Mesquita. Feminismo, Justiça Social e Cidadania na América Latina. In: MELO, Hildete Pereira de; PISCITELLI, Adriana; MALUF, Sônia Weidner; PUGA, Vera Lucia (orgs.). Olhares Feministas. Ministério da Educação: UNESCO. Coleção Educação para Todos. Brasília/DF, v. 10. p. 510, 2006. Disponível em:

http://portal.mec.gov.br/index.php?option=com docman\&view=download\&alias=639vol10feministas-pdf\&category slug=documentos-pdf\&ltemid=30192. Acesso em: 10 nov. 2018.

SANTOS, José Jackson Reis dos. Especificidades dos saberes para a docência na educação de pessoas jovens e adultas. Revista Práxis Educacional, Vitória da Conquista, v. 6, n. 8, jan./jun. 2010. Disponível em:

https://periodicos2.uesb.br/index.php/praxis/article/view/623. Acesso em: 16 nov. 2018.

SPARTA, Mônica; GOMES, William. Importância atribuída ao ingresso na Educação Superior por alunos do Ensino Médio. Revista Brasileira de Orientação Profissional. Porto Alegre, vol. 6, n. 2. p. 45-53. 2005. Disponível em: http://www.ufrgs.br/museupsi/lafec/16.pdf. Acesso em: 12 nov. 2018.

VASCONCELOS, Natália Batista. Programa Nacional de Assistência Estudantil: uma análise da evolução da assistência estudantil ao longo da história da Educação Superior no Brasil.

Ensino em Re-vista. Uberlândia, v. 17, p. 599-616. 2010. Disponível em: http://www.seer.ufu.br/index.php/emrevista/article/view/11361/6598. Acesso em: 14 maio 2018. 


\section{ABOUT THE AUTHORS}

Sônia Maria Alves de Oliveira Reis: PhD in Education from the Federal University of Minas Gerais. Adjunct professor at the State University of Bahia where she works in undergraduate and lato sensu specialization courses. She is an external professor at the Postgraduate Program in Education (PPGEd / UESB), area coordinator of the Institutional Program for Teaching Initiation Scholarship (Pibid), leader of the Center for Studies, Research and Educational Extension Paulo Freire (NEPE / CNPQ). Coordinator of the Interinstitutional Doctorate. Dinter - UNEB / UFMG. E-mail: sonia uneb@hotmail.com.

Orcid: http://orcid.org/0000-0003-0129-0719

Samara Gomes Aguiar: Degree in Pedagogy from the State University of Bahia - UNEB / DEDC - Campus XII. Master's student in the line of research: Curricula, Educational Practices and Differences of the Graduate Program in Education at the State University of Southwest Bahia (PPGEd / UESB). Member of the Center for Studies, Research and Educational Extension Paulo Freire (NEPE / CNPQ). FAPESB Scholarship. E-mail: samaraaguiarcte@hotmail.com.

Orcid: https://orcid.org/0000-0003-4259-4145

Valquiria Normanha Paes: Graduated in the Pedagogy Course from the State University of Bahia. Department of Education - Campus XII of Guanambi / BA. Linked to the line of research Education of the Field, Education of Youths and Adults and Social Movements of the Research Group of CNPQ - Center for Study Research and Educational Extension Paulo Freire - NEPE of DEDC-XII. E-mail: valquirianpaes@hotmail.com.

Orcid: https://orcid.org/0000-0003-1084-6977 